\title{
Factors associated with the knowledge and attitude of adolescents regarding male condom use
}

\author{
Fatores associados ao conhecimento e atitude de adolescentes quanto ao uso de preservativo masculino
}

Factores relacionados al conocimiento y conducta de adolescentes cuanto al uso del preservativo masculino

\section{Vitória Caroline da Cunha Rodrigues' ORCID: 0000-0002-4240-6469}

Gabriella Farias Lopes' ORCID: 0000-0002-5767-5055

Giovanna Evelyn Luna Silveira' ORCID: 0000-0002-6594-9634

Isabelle Barros Sousa' ORCID: 0000-0001-9019-3341

Marcela Matias Sena" ORCID: 0000-0003-2777-2417

Thays Silva de Souza Lopes" ORCID: 0000-0001-9012-3917

Priscila de Souza Aquino' ORCID: 0000-0003-4976-9817

'Universidade Federal do Ceará. Fortaleza, Ceará, Brazil. "Escola de Saúde Pública do Ceará. Fortaleza, Ceará, Brazil.

How to cite this article:

Rodrigues VCC, Lopes GF, Silveira GEL, Sousa IB, Sena MM, Lopes TSS, et al. Factors associated with the knowledge and attitude of adolescents regarding male condom use. Rev Bras Enferm. 2021;73(Suppl 4):e20190452. doi: http://dx.doi.org/10.1590/0034-7167-2019-0452

Corresponding author:

Vitoria Caroline da Cunha Rodrigues E-mail: vitoriaccrenf@gmail.com

EDITOR IN CHIEF: Antonio José de Almeida Filho ASSOCIATE EDITOR: Hugo Fernandes

Submission: 07-22-2020

Approval: 08-28-2020

\begin{abstract}
Objective: Identify factors associated with the knowledge and attitude regarding male condom use in school adolescents. Methods: Cross-sectional, quantitative, Knowledge, Attitude, and Practice survey, conducted with 114 adolescents from a public state high school from August to October 2017, in Fortaleza, Ceará, Brazil. Results: The assumption of having sufficient knowledge regarding safe sex, not having a casual/dating partner, and having had three or more sexual partners in the last three months affected adequate knowledge. Higher education of the mother and not talking to the mother about sex were factors that influenced the inappropriate attitude of the participants. Conclusion: The knowledge and attitude of adolescents are influenced both by their previous sexual relations and by their relationship with their mother and the level of her schooling. Thus, it is essential that health institutions promote actions aimed at sex education, with support from schools and health professionals in general.

Descriptors: Sexuality; Nursing; Knowledge; Attitude; Condoms.
\end{abstract}

\section{RESUMO}

Objetivo: Identificar fatores associados ao conhecimento e atitude sobre uso do preservativo masculino em adolescentes escolares. Método: Estudo quantitativo, transversal, do tipo inquérito Conhecimento, Atitude e Prática, realizado com 114 adolescentes de escola estadual de ensino médio no período de agosto a outubro de 2017, em Fortaleza, Ceará. Resultados: Considerar seu conhecimento sobre sexo seguro suficiente, não ter parceiro casual/ficante, e ter tido três ou mais parceiros sexuais nos últimos três meses afetaram o conhecimento adequado. Maior escolaridade da mãe e não conversar com a mãe sobre sexo foram fatores que influenciaram a atitude inadequada dos participantes. Conclusão: O conhecimento e a atitude dos adolescentes são influenciados tanto por suas relações sexuais prévias como pela relação com a mãe e pela escolaridade dela. Assim, torna-se imprescindível que as instituições de saúde promovam ações voltadas à educação sexual, mediante apoio das escolas e dos profissionais de saúde em geral.

Descritores: Sexualidade; Enfermagem; Conhecimento; Atitude; Preservativos.

\section{RESUMEN}

Objetivo: Identificar factores relacionados al conocimiento y conducta sobre el uso del preservativo masculino por adolescentes escolares. Métodos: Estudio cuantitativo, transversal, del tipo investigación Conocimiento, Conducta y Práctica, realizado con 114 adolescentes de escuela estatal de educación secundaria en el período de agosto a octubre de 2017, en Fortaleza, Ceará. Resultados: Considerar conocimiento sobre sexo seguro suficiente, no tener pareja ocasional y haber tenido tres o más parejas sexuales en los últimos tres meses, afectaron el conocimiento adecuado. Mayor escolaridad de la madre y no charlar con ella sobre sexo han sido factores que influenciaron la conducta inadecuada de los participantes. Conclusión: El conocimiento y la conducta de los adolescentes son influenciados tanto por sus relaciones sexuales previas como por la relación con la madre y por la escolaridad de ella. Así, se vuelve imprescindible que instituciones de salud promuevan acciones vueltas a la educación sexual, mediante apoyo de las escuelas y de profesionales de salud en general. Descriptores: Sexualidad; Enfermería; Conocimiento; Conducta; Preservativos. 


\section{INTRODUCTION}

Adolescence, a period that comprises the age group of 10 to 19 years, constitutes physical and organic transformations combined with the perception of sexual and occupational identity. This phase involves intense biopsychosocial changes as it represents the transformation to adulthood and the development of autonomy towards parents ${ }^{(1)}$. Adolescents often have incongruous behaviors related to the constant search to find their real personality and, in some cases, they are negligent with health care.

In the context of search for new experiences and the exploration of new environments, situations, and relationships, adolescents can be involved in numerous situations of vulnerability, which can have negative consequences in the short, medium, or long term. These include, for example, use of alcohol, cigarettes, and drugs, antisocial conduct, risky sexual behavior, among others ${ }^{(2)}$.

Adolescents are a vulnerable population to sexually transmitted infections (STIs), whether in underdeveloped or developed countries, which can be perceived by several factors, including biological, psychological, social, and economic. However, research indicates that, even with the dissemination in the media and information, adolescents and young people still have doubts regarding the prevention of transmission of the human immunodeficiency virus (HIV)/STIs and some resistance to the use of condoms, making them susceptible to and increasing the incidences of these diseases. Regarding the vulnerability to STIs, Brazilian statistics show a trend in the increase of AIDS cases among young people, as well as a higher incidence of STIs in this population ${ }^{(3)}$.

Research carried out in public schools in Rio Grande do Sul showed that adolescents have adequate knowledge for the prevention of STIs, but this knowledge does not determine the adoption of effective attitudes to avoid them. In this thematic area, it was found that adolescents, despite having the knowledge about what an STI is, are vulnerable because they present behaviors that expose them, such as not using condoms in all sexual relations, consumption of alcoholic beverages, and illicit drugs ${ }^{(4)}$.

In view of the above, there is a need to investigate factors associated with the knowledge and attitude of school adolescents to identify the main vulnerabilities. Thus, contributing to directing professional health practices to this audience, as well as minimizing gaps in scientific knowledge.

\section{OBJECTIVE}

Identify the factors associated with the knowledge and attitude on the use of male condoms in school adolescents.

\section{METHODS}

\section{Ethical aspects}

The project was approved by the Research Ethics Committee, according to Resolution No. 466/12 ${ }^{(5)}$ of the Ministry of Health.

\section{Design, place of study, and period}

Cross-sectional, quantitative, Knowledge, Attitude, and Practice (KAP) survey, guided by the STROBE tool. Data collection was carried out from August to October 2017 at a state public high school in Fortaleza, state of Ceará.

\section{Population and sample: inclusion and exclusion criteria}

The study population consisted of 500 high school students aged 14 to 19 years, considering the age group classification as pre-adolescent (10 to 14 years) and adolescent (15 to 19 years), according to the World Health Organization ${ }^{(6)}$. The study sample was non-probabilistic for convenience. Sample calculation was performed for finite population, which estimates a minimum sample size. When applying the formula, having the total population of students enrolled in the school, a sample size of 114 students was obtained. Inclusion criterion were that students be regularly enrolled in the institution and present on the day of data collection.

\section{Study protocol}

Data collection was performed using a semi-structured questionnaire, filled out on school premises and in the presence of the team responsible for the collection. Participants were placed separately within the room offered by the institution and instructed not to talk during the collection period.

The questionnaire addressed questions that included sociodemographic, sexual, and reproductive data of the respondents, in addition to the investigation based on the KAP survey. However, the present study evaluated only the attitude and knowledge about the male condom. The questionnaire was evaluated for appearance and content by three nurses, each with more than three years of experience in Adolescent Health and Sexual and Reproductive Health. To validate the content of the questionnaire, the Content Validity Index (CVI) was used, which is based on the mathematical equation of the proportion of items that received values between 3 and 4 (relevant and very relevant) ${ }^{(7)}$.

In the study, knowledge regarding the use of the male condom as a STI/HIV preventive method was considered appropriate when the adolescent reported having heard about the male condom, was aware of its general STI/HIV prevention function, including unwanted pregnancies, and managed to mention at least three precautions necessary for correct use of the method. On the other hand, knowledge was inadequate when the adolescent claimed to have never heard of the male condom or had already heard about it, but did not know that it's purpose was to prevent STIs/HIV in general or unwanted pregnancies; or when the adolescent was not able to mention at least two precautions necessary for its correct use.

Regarding the attitude assessment, it was considered adequate when the adolescent declared that the use of the male condom was always necessary in all sexual practices; and inadequate when the adolescent reported that using the male condom was unnecessary, barely necessary, or had no opinion about its need.

\section{Analysis of results and statistics}

The tabulation and crossing of the data were performed using the IBM SPSS (Statistical Package for Social Sciences) program, version 22.0. For quantitative variables, absolute, relative, and average frequencies were used. The association of outcome 
variables (adequate knowledge and attitude) with predictors (sociodemographic, of social and sexual influences) was performed using the Fischer test, likelihood ratio, and Pearson's chi-squared test, considering $p<0.05$ as significant, in a $95 \%$ confidence interval. When the data were unavailable due to the lack of response from the participants, only the valid responses for the crossings were used.

\section{RESULTS}

114 adolescents participated in the study, 63 of whom were female, 50 male and 1 not informed, with an average of 16.34 years and an average family income of $R \$ 2,458.35$. All were high school students, 48 were in the first year; 41 , the second year; and 25 , the third year. Regarding the marital status of the participants, 112 answered this question, 40 did not have a partner, 39 had a casual partner, 20 had a steady partner, and 13 never had a partner. Of the participants, 61 lived with both parents. They were predominantly practitioners of the Catholic religion (53); parents with 9 or more years of education and mothers with 12 or more years of education.

Table 1 shows the sociodemographic data of the interviewees associated with knowledge and attitude about the male condom.

It is observed that the age and sex of the adolescents did not significantly influence the results, but with regard to their gender, $p=0.057$ was observed, close to the significance value. Family income, living with both parents, and the father's years of education did not affect the knowledge or attitude of the adolescents, however, the sons whose mother had a higher level of education, more than 12 years of study, had a higher rate of inappropriate attitude, 36 .
For each variable in Table 1, the following number of participants with missing data was identified: for age, 5 people did not respond; for sex, 1 person; for family income, 37 people; living with parents or years of education by the mother and father there were no missing data.

Table 2 shows the association of social influences with the adolescents' knowledge and attitude.

As shown in Table 2, it was observed that two variables obtained significance in their results. Of the 61 adolescents who considered their knowledge of safe sex "sufficient", 49 effectively had adequate knowledge ( $p=0.003)$, with a chance ratio of 3.5 , however, the same did not happen with the attitude. Speaking to the father about sex did not impact the results, however, it was identified that not speaking to the mother negatively affected the attitude of the adolescents, as it was found that 61 participants who did not talk about sex with the mother had an inappropriate attitude, with odds ratio of 3.8.

Regarding the variables in Table 2, some participants did not respond: the self-assessment of knowledge regarding safe sex, 1 person; for the conversation with the father about sex, 11 people; speaking to the mother about sex, 2 people; however, when it came to talking to friends about sex, no one failed to respond.

Table 3 contains the association of sexual variables with the knowledge and attitude of the interviewed adolescents.

Regarding Table 3, out of the total number of participants, 59 had already had sexual intercourse, however, this fact did not lead to significant results in the knowledge and attitude of the students, as well as having or not having used a condom during the first sexual intercourse. Of those who claimed to have a casual/dating partner, 17 were noted having inadequate knowledge, whereas the same

Table 1 - Association of sociodemographic variables with the knowledge and attitude of the interviewed school adolescents, Fortaleza, Ceará, Brazil, August to November 2017

\begin{tabular}{|c|c|c|c|c|c|c|c|c|c|c|}
\hline \multirow{3}{*}{ Sociodemographic Variables } & \multicolumn{4}{|c|}{ Knowledge } & \multicolumn{6}{|c|}{ Attitude } \\
\hline & \multicolumn{2}{|c|}{ Adequate } & \multicolumn{2}{|c|}{ Inadequate } & \multirow[t]{2}{*}{$p$} & \multicolumn{2}{|c|}{ Adequate } & \multicolumn{2}{|c|}{ Inadequate } & \multirow[t]{2}{*}{$p$} \\
\hline & $\mathbf{n}$ & $\%$ & $\mathbf{n}$ & $\%$ & & $\mathbf{n}$ & $\%$ & $\mathbf{n}$ & $\%$ & \\
\hline \multicolumn{11}{|l|}{ Age } \\
\hline Up to 17 years & 42 & 49.4 & 43 & 50.6 & \multirow{2}{*}{$0.063^{\ddagger}$} & 12 & 14.1 & 73 & 85.9 & \multirow{2}{*}{$0.486^{\ddagger}$} \\
\hline$\geq 18$ years & 17 & 70.8 & 7 & 29.2 & & 4 & 16.7 & 20 & 83.3 & \\
\hline \multicolumn{11}{|l|}{ Enrolment } \\
\hline First year & 23 & 47.9 & 25 & 52.1 & \multirow{3}{*}{0.254} & 7 & 14.6 & 41 & 85.4 & \multirow{3}{*}{0.506} \\
\hline Second year & 22 & 53.7 & 19 & 46.3 & & 4 & 9.8 & 37 & 90.2 & \\
\hline Third year & 17 & 68 & 8 & 32 & & 5 & 20 & 20 & 80 & \\
\hline \multicolumn{11}{|l|}{ Gender } \\
\hline Female & 32 & 64 & 18 & 36 & \multirow{2}{*}{$0.057^{\ddagger}$} & 5 & 10 & 45 & 90 & \multirow{2}{*}{$0.259^{+}$} \\
\hline Male & 29 & 46 & 34 & 54 & & 11 & 17.5 & 52 & 82.5 & \\
\hline \multicolumn{11}{|l|}{ Family income } \\
\hline Up to 1 minimum wage salary & 6 & 75 & 2 & 25 & \multirow{2}{*}{$0.463^{*}$} & 2 & 25 & 6 & 75 & \multirow{2}{*}{$0.234^{*}$} \\
\hline$\geq$ minimum wage & 40 & 58 & 29 & 42 & & 7 & 10.1 & 62 & 89.9 & \\
\hline \multicolumn{11}{|l|}{ Lives with parents } \\
\hline With both & 35 & 57.4 & 26 & 42.6 & \multirow{3}{*}{$0.615^{* *}$} & 10 & 16.4 & 51 & 83.6 & \multirow{3}{*}{$0.102^{* *}$} \\
\hline With only one & 21 & 53.8 & 18 & 46.2 & & 6 & 33 & 33 & 84.6 & \\
\hline With others & 6 & 42.9 & 8 & 57.1 & & 0 & 0 & 14 & 100 & \\
\hline \multicolumn{11}{|c|}{ Father's number of years in education } \\
\hline Up to 9 years & 7 & 63.6 & 4 & 36.4 & \multirow{3}{*}{$0.806^{* *}$} & 3 & 27.3 & 8 & 72.7 & \multirow{3}{*}{$0.200^{* *}$} \\
\hline 10 to 12 years & 26 & 53.1 & 23 & 46.9 & & 4 & 8.2 & 45 & 91.8 & \\
\hline$\geq 12$ years & 29 & 53.7 & 25 & 46.3 & & 9 & 16.7 & 45 & 83.3 & \\
\hline \multicolumn{11}{|c|}{ Mothers's number of years in education } \\
\hline Up to 9 years & 5 & 38.5 & 8 & 61.5 & \multirow{3}{*}{$0.231^{* *}$} & 2 & 15.4 & 11 & 84.6 & \multirow{3}{*}{$0.023^{* *}$} \\
\hline 10 to 12 years & 39 & 60.9 & 25 & 39.1 & & 13 & 20.3 & 51 & 79.7 & \\
\hline$>12$ years & 18 & 48.6 & 19 & 51.4 & & 1 & 2.7 & 36 & 97.3 & \\
\hline
\end{tabular}


Table 2 - Association of social influence variables with the knowledge and attitude of the interviewed school adolescents, Fortaleza, Ceará, Brazil, August to November 2017

\begin{tabular}{|c|c|c|c|c|c|c|c|c|c|c|}
\hline \multirow{3}{*}{ Social influence variables } & \multicolumn{4}{|c|}{ Knowledge } & \multicolumn{6}{|c|}{ Attitude } \\
\hline & \multicolumn{2}{|c|}{ Adequate } & \multicolumn{2}{|c|}{ Inadequate } & \multirow{2}{*}{$p$} & \multicolumn{2}{|c|}{ Adequate } & \multicolumn{2}{|c|}{ Inadequate } & \multirow[t]{2}{*}{$\boldsymbol{p}$} \\
\hline & & $\%$ & n & $\%$ & & $\mathbf{n}$ & $\%$ & $\mathbf{n}$ & $\%$ & \\
\hline \multicolumn{11}{|c|}{ Knowledge self-assessment on safe sex } \\
\hline Sufficient & 49 & 63.6 & 12 & 33.6 & \multirow{2}{*}{$0.003^{\ddagger}$} & 8 & 10.4 & 69 & 89.6 & \multirow{2}{*}{$0.093^{*}$} \\
\hline Insufficient & 28 & 36.3 & 24 & 66.7 & & 8 & 22.2 & 28 & 77.8 & \\
\hline \multicolumn{11}{|l|}{ Speaks to the father about sex } \\
\hline Yes & 9 & 60 & 6 & 40 & \multirow{2}{*}{$0.755^{\ddagger}$} & 2 & 13.3 & 13 & 86.7 & \multirow{2}{*}{$1.000^{*}$} \\
\hline No & 49 & 55.7 & 39 & 44.3 & & 13 & 14.8 & 75 & 85.2 & \\
\hline \multicolumn{11}{|c|}{ Speaks to the mother about sex } \\
\hline Yes & 27 & 58.7 & 19 & 41.3 & \multirow{2}{*}{$0.553^{\ddagger}$} & 11 & 23.9 & 35 & 76.1 & \multirow{2}{*}{$0.015^{\ddagger}$} \\
\hline No & 35 & 53 & 31 & 47 & & 5 & 7.6 & 61 & 92.4 & \\
\hline \multicolumn{11}{|l|}{ Speaks to friends about sex } \\
\hline Yes & 53 & 85.5 & 9 & 14.5 & \multirow[b]{2}{*}{$0.897^{\ddagger}$} & 15 & 15.5 & 82 & 84.5 & \multirow[b]{2}{*}{$0.459^{*}$} \\
\hline No & 44 & 84.6 & 8 & 15.4 & & 1 & 5.9 & 16 & 94.1 & \\
\hline
\end{tabular}

Table 3 - Association of sexual variables with the knowledge and attitude of interviewed school adolescents, Fortaleza, Ceará, Brazil, August to November 2017

\begin{tabular}{|c|c|c|c|c|c|c|c|c|c|c|}
\hline \multirow{3}{*}{ Sexual variables } & \multicolumn{4}{|c|}{ Knowledge } & \multicolumn{6}{|c|}{ Attitude } \\
\hline & \multicolumn{2}{|c|}{ Adequate } & \multicolumn{2}{|c|}{ Inadequate } & \multirow[t]{2}{*}{$\boldsymbol{p}$} & \multicolumn{2}{|c|}{ Adequate } & \multicolumn{2}{|c|}{ Inadequate } & \multirow[t]{2}{*}{$\boldsymbol{p}$} \\
\hline & $\mathbf{n}$ & $\%$ & $\mathbf{n}$ & $\%$ & & $\mathbf{n}$ & $\%$ & $\mathbf{n}$ & $\%$ & \\
\hline \multicolumn{11}{|l|}{ Sexual initiation } \\
\hline Yes & 31 & 52.5 & 28 & 47.5 & \multirow[t]{2}{*}{$0.682^{\ddagger}$} & 7 & 11.9 & 52 & 88.1 & \multirow[t]{2}{*}{$0.490^{\ddagger}$} \\
\hline No & 31 & 56.4 & 24 & 43.6 & & 9 & 16.4 & 46 & 83.6 & \\
\hline \multicolumn{11}{|c|}{ Use of condom on the first sexual relation } \\
\hline Yes & 18 & 58.1 & 13 & 41.9 & \multirow[t]{2}{*}{$0.450^{\ddagger}$} & 4 & 12.9 & 27 & 87.1 & \multirow[t]{2}{*}{$1.000^{*}$} \\
\hline No & 13 & 48.1 & 14 & 51.9 & & 3 & 11.1 & 24 & 88.9 & \\
\hline \multicolumn{11}{|l|}{ Sexual orientation } \\
\hline Heterosexual & 20 & 47.6 & 22 & 52.4 & \multirow[t]{4}{*}{$0.151^{* *}$} & 3 & 7.1 & 39 & 92.9 & \multirow[t]{4}{*}{$0.105^{* *}$} \\
\hline Homosexual & 3 & 50 & 3 & 50 & & 1 & 16.7 & 5 & 83.3 & \\
\hline Bisexual & 5 & 71.4 & 2 & 28.6 & & 3 & 42.9 & 4 & 57.1 & \\
\hline Other & 3 & 100 & 0 & 0 & & 0 & 0 & 3 & 100 & \\
\hline \multicolumn{11}{|c|}{ Regular/fixed partner } \\
\hline Yes & 18 & 58.1 & 13 & 41.9 & \multirow{2}{*}{$0.370^{\ddagger}$} & 5 & 16.1 & 26 & 83.9 & \multirow{2}{*}{$0.436^{*}$} \\
\hline No & 12 & 46.2 & 14 & 53.8 & & 2 & 7.7 & 24 & 92.3 & \\
\hline \multicolumn{11}{|c|}{ Casual/dating partner } \\
\hline Yes & 9 & 34.6 & 17 & 65.4 & \multirow{2}{*}{$0.017^{\ddagger}$} & 3 & 11.5 & 23 & 88.5 & \multirow{2}{*}{$1.000^{*}$} \\
\hline No & 20 & 66.7 & 10 & 33.3 & & 4 & 13.3 & 26 & 86.7 & \\
\hline \multicolumn{11}{|c|}{ Number of partners in life } \\
\hline Zero & 0 & 0 & 1 & 100 & \multirow[t]{3}{*}{$0.463^{* *}$} & 0 & 0 & 1 & 100 & \multirow[t]{3}{*}{$0.799^{* *}$} \\
\hline 1 to 3 & 19 & 52.8 & 17 & 47.2 & & 5 & 13.9 & 31 & 86.1 & \\
\hline Above 3 & 11 & 55 & 9 & 45 & & 2 & 10 & 18 & 90 & \\
\hline \multicolumn{11}{|c|}{ Number of partners in the past 3 months } \\
\hline Zero & 7 & 63.6 & 4 & 36.4 & \multirow[t]{3}{*}{$0.032^{* *}$} & 1 & 9.1 & 10 & 90.9 & \multirow[t]{3}{*}{$0.507^{* *}$} \\
\hline 1 to 3 & 18 & 43.9 & 23 & 56.1 & & 6 & 14.6 & 35 & 85.4 & \\
\hline Above 3 & 4 & 100 & 0 & 0 & & 0 & 0 & 4 & 100 & \\
\hline
\end{tabular}

Note: ${ }^{*}$ Fischer Test ${ }^{*}$ Likelihood ratio $\neq$ Chi-squared test.

was not observed in those who had a fixed partner. It was evident that adolescents who had more than 3 casual partners in the last 3 months had significantly adequate knowledge compared to the others.

\section{DISCUSSION}

It was noticed in the study, a profile of female students, single, who live with their parents and have an income below three minimum wages. The average of an early age sexual engagement and the low frequency of condom use reflects a phenomenon already mentioned in other studies ${ }^{(8-9)}$ and can have consequences such as early pregnancy, STIs, and greater conflict with the family.
Among the adolescents surveyed, it was seen that the adequate knowledge of female participants in relation to the use of the male condom came close to significance when compared to the knowledge of the male participants. Although there is no statistical significance, other studies have already highlighted this association. In a study by Carvalho ${ }^{(10)}$, women presented high averages of knowledge compared to the opposite sex. This may be the result of a greater concern among women towards the possibility of an unplanned pregnancy and greater search for information about contraceptive methods.

The matter of family income did not influence the knowledge or the appropriate attitude of the adolescents. However, a study 
conducted in Colombia with 1,100 adolescents showed that the majority belonged to low income levels (strata 2 and 3 ) within a scale ranging from 0 (lowest) to 6 (highest) and had a low score on the Knowledge of HIV and other STIs (12.69 vs. 24), which includes questions about condom use ${ }^{(11)}$. It is believed that one of the factors related to this lack of knowledge is the lack of accessible networks for obtaining correct information about contraceptive methods and ways to prevent STIs.

Although no statistical significance was found, the knowledge of students in the 3rd year was more adequate $(68 \%)$ than the knowledge of those in the 1 st year $(47.9 \%)$ and the 2 nd year (53.7\%). The same happened regarding attitude: the adolescents of the $3 \mathrm{rd}$ year were more suitable (20\%) than those of the $1 \mathrm{st}$ year (14.6\%) and the 2nd year (9.8\%). Nevertheless, a 2017 study showed a positive and significant correlation $(p=0.001)$ between age and adolescents' knowledge about sexuality, stating that those in more advanced grades had higher averages of knowledge on the subject ${ }^{(10)}$.

In the present study, it was also observed that the children of mothers with some level of education, especially those with more than 12 years of study, had a higher rate of inappropriate attitude. With the greater insertion of women in higher education courses and in the job market, and professional achievement and financial independence as goals in their life, the time dedicated to work and studies results in a lesser participation of the mother in household tasks and in the raising of children ${ }^{(12)}$, often creating an absence of a figure that would be the center of the family and make parents more involved in the care of their children ${ }^{(13)}$.

In contrast, a study carried out in Lisbon, Portugal, with 1,545 adolescents, showed that adolescents whose mothers had higher education presented higher values in knowledge about sexuality than the group of adolescents whose mothers had only the first cycle of basic education ${ }^{(10)}$.

The adolescents who considered their knowledge of safe sex to be sufficient, indeed presented adequate knowledge; however, in relation to attitude, the same behavior was not observed. Attitude involves having opinions, feelings, predispositions, and beliefs, which are directed to a person, objective, or situation (14). Therefore, just having adequate knowledge about condoms does not guarantee correct attitude and practice.

A study showed that adolescents have a high level of knowledge about ways to prevent HIV infection, mainly in the recognition of the male condom as the best way to avoid infection. However, there was a drop in condom use in all age groups, adding to the argument that just passing on information about safe sexual behaviors is not enough for change ${ }^{(15)}$.

It was found that not talking to the mother negatively influences the attitude of the adolescents, as it was found that most participants who did not talk about sex with the mother had an inappropriate attitude. This finding coincides with a study in which it is evident that the uncomfortable relationship between mothers and children for reasons such as fear and shame makes sexuality a taboo subject, preventing an open discussion of the topic and exposing adolescents to the dangers of infection (16).

Considering the participants who had already had sexual intercourse, it was assessed that most of them did not have adequate knowledge and attitude. This fact is in line with a study on adherence to the use of male condoms by adolescents, since a large part of adolescents who have already started their sexual life use condoms in an alternate and discontinuous way, are unconcerned about the risks of acquiring diseases, and their attentions are aimed at unwanted pregnancies, influenced by immaturity as to the existing dangers, thus adopting an erroneous posture ${ }^{(9)}$.

It was found that the participants with a casual partner had more inadequate knowledge when compared to those who had a steady partner, but the stability of the relationships had no influence on an adequate knowledge or attitude. A study carried out in Colombia showed medium to low knowledge about HIV and other STIs in a population of adolescents in which the majority did not have a partner, $711(64.6 \%)^{(11)}$. On the other hand, adolescents with a steady partner tend to decrease the frequency of condom use due to the confidence in their partner, thus seeking other contraceptive methods ${ }^{(17)}$.

Adequate knowledge was observed among young people who had more than three sexual partners in the past three months. A study carried out in the city of Cuiabá-MT revealed that more than $70 \%$ of the interviewed adolescents had had more than one sexual partner in the last three months, which shows the casualness of sexual relations and a lack of habit of prevention ${ }^{(18)}$. This increase in sexual partnerships in adolescence may be related to an opening to sexuality, and the non-use of preventive methods is related to the phase of experimentation evident in this age group and is causally linked to risky behaviors.

\section{Limitations of the Study}

The study carried out presented limitations as to its representativeness, as the sample consisted of students from a single state public school, thus restricting reality to just one location. As it is a sample of underage adolescents, the non-return of parental authorization data was also a limiting factor in the research. In addition, it is worth mentioning that the vulnerabilities of adolescents, not only individual but also social and programmatic, interfere in the directing of health actions.

\section{Contributions to the Field of Nursing}

In view of the increase in cases of STIs and AIDS in adolescents, as well as unwanted pregnancies, studies that provide a situational diagnosis of adolescents' vulnerabilities are important to support the creation of new health policies. Identification of individual, social and, programmatic vulnerabilities of adolescents can direct health actions of professionals towards this audience, whether in the spaces of primary health care units, or even in the school itself.

\section{CONCLUSION}

It was concluded that the knowledge and attitude about the male condom were influenced by several factors, such as the mother's years of education, the self-assessment of knowledge about safe sex, talking to the mother about sex, casual/dating partner, and number of partners in the past three months. Knowledge was positively influenced by the sufficient self-assessment 
of knowledge on safe sex, not having a casual/dating partner, and having more than three partners in the last three months. The attitude towards condom use was negatively influenced by greater maternal education and absence of dialogue about sex with the mother.

The research carried out proves the need for educational actions with a focus on sex education to increase the knowledge and attitude of adolescents in view of the phase of greatest vulnerability in which they find themselves. The deficiencies found can be alleviated by addressing the issue in families and in educational institutions, aiming at the support that adolescents need to experience their sexuality in a safe and balanced way.

Therefore, further studies on sexuality with adolescents are essential, as they serve as a basis for directing campaigns and actions, aiming at further clarifying the theme to adolescents.

\section{FUNDING}

Tutorial Education Program/National Fund for Educational Development/Minister of Education.

\section{REFERENCES}

1. Oliveira PS, Abud ACF, Inagaki ADM, Alves JAB, Matos KF. Vulnerability of adolescents to sexually transmissible diseases in primary care. Rev Enferm UFPE. 2018;12(3):753-62. doi: 10.5205/1981-8963-v12i3a25063p753-762-2018

2. Alves SCF, Zappe JG, Dell'Aglio DD. Índice de Comportamentos de Risco: construção e análise das propriedades psicométricas. Estud Psicol. 2015;32(3):371-82. doi: 10.1590/0103-166X2015000300003

3. Chaves ACP, Bezerra EO, Pereira MLD, Wolfgang W. Conhecimentos e atitudes de adolescentes de uma escola pública sobre a transmissão sexual do HIV. Rev Bras Enferm. 2014;67(1):48-53. doi: 10.5935/0034-7167.20140006

4. Silva AT, Jacob MHVM, Hirdes A. Conhecimento de adolescentes do ensino médio sobre DST/AIDS no sul do Brasil. Aletheia [Internet]. 2015 [cited 2019 Mar 16];(46):34-49. Available from: http://pepsic.bvsalud.org/scielo. php?script=sci_arttext\&pid=S1413-03942015000100004\&lng=pt

5. Ministério da Saúde (BR). Resolução n 466/12, de 12 de dezembro de 2012. Dispõe sobre pesquisa envolvendo seres humanos [Internet]. Brasília: Ministério da Saúde; 2012 [cited 2020 Jun 16]. Available from: http://bvsms.saude.gov.br/bvs/saudelegis/cns/2013/ res0466_12_12_2012.html

6. Organização Mundial da Saúde. Health for the world's adolescents: a second chance in the second decade [Internet]. 2014 [cited 2020 Jun 16]. Available from: https://apps.who.int/adolescent/second-decade/files/1612_MNCAH_HWA_Executive_Summary.pdf

7. Alexandre NMC, Coluci MZO. Validade de conteúdo nos processos de construção e adaptação de instrumentos de medidas. Cien Saude Coletiva. 2011;16(7):3061-68. doi: 10.1590/S1413-81232011000800006

8. Cruz LZ, Andrade MS, Paixão GPN, Silva RS, Maciel KMN, Fraga CDS. Conocimiento de los adolescentes sobre anticoncepción y infecciones sexualmente transmisibles. Adolesc Saude [Internet]. 2018 [cited 2019 Mar 16];15(2):7-18. Available from: http://www.adolescenciaesaude. com/audiencia_pdf.asp?aid2 $=714 \&$ nomeArquivo $=\mathrm{v} 15 \mathrm{n} 2 \mathrm{a} 02 . \mathrm{pdf}$

9. Santos CP, Barboza ECS, Freitas NO, Almeida JC, Dias AC, Araújo EC. Adesão ao uso do preservativo masculino por adolescentes escolares. Rev Bras Pesqui Saúde [Internet]. 2016 [cited 2019 Mar 16];18(2):60-70. Available from: http://periodicos.ufes.br/RBPS/article/view/15085/10687

10. Carvalho CP, Pinheiro MRM, Gouveia JP, Vilar DR. Conhecimentos sobre sexualidade: Construção e validação de um instrumento de avaliação para adolescentes em contexto escolar. Educ Sex Adolesc Quest Rev Port Educ. 2017; 30(2):249-74. doi: 10.21814/rpe.9032

11. Morales A, Vallejo-Medina P, Abello-Luque D, Saavedra-Roa A, García-Roncallo P, Gomez-Lugo M, et al. Sexual risk among Colombian adolescents: knowledge, attitudes, normative beliefs, perceived control, intention, and sexual behavior. BMC Public Health. 2018;18:1377. doi: 10.1186/s12889-018-6311-y

12. Borges CC. Mudanças nas trajetórias de vida e identidades de mulheres na contemporaneidade. Psicol Estud. 2013;18(1):71-81. doi: 10.1590/S1413-73722013000100008

13. Gomes QS, Alvarenga P. O Envolvimento Paterno em Famílias de Diferentes Níveis Socioeconômicos. Psic.: Teor. e Pesq. 2016; 32(3):1-9. doi: http://dx.doi.org/10.1590/0102-3772e323216.

14. Andrade SSC, Zaccara AAL, Leite KNS, Brito KKG, Soares MJGO, Costa MML, et al. Knowledge, attitude and practice of condom use by women of an impoverished urban area. Rev Esc Enferm USP. 2015;49(3):364-71. doi: 10.1590/S0080-623420150000300002

15. Genz N, Meincke SMK, Carret MLV, Corrêa ACL, Alves CN. Sexually transmitted diseases: knowledge and sexual behavior of adolescents. Texto Contexto Enferm. 2017;26(2):e5100015. doi: 10.1590/0104-07072017005100015

16. Shakour M, Salehi K, Yamani N. Reproductive health need assessment of adolescent boys and girls during puberty: a qualitative study. Int J Pediatr. 2018;6(9):8195-205. doi: 10.22038/ijp.2018.29648.2602

17. Francisco MTR, Fonte VRF, Pinheiro CDOP, Silva MES, Spindola T, Lima DVM. Condom use among participants of the Carnival - gender perspective. Esc Anna Nery. 2016;20(1):106-113. doi: 10.5935/1414-8145.20160015

18. Lima FCA, Jesus FB, Martins CBG, Souza SPS, Matos KF. A experiência e atitudes de adolescentes frente à sexualidade. Mundo Saúde. 2013;37(4):385-93. doi: 10.15343/0104-7809.2013374385393 